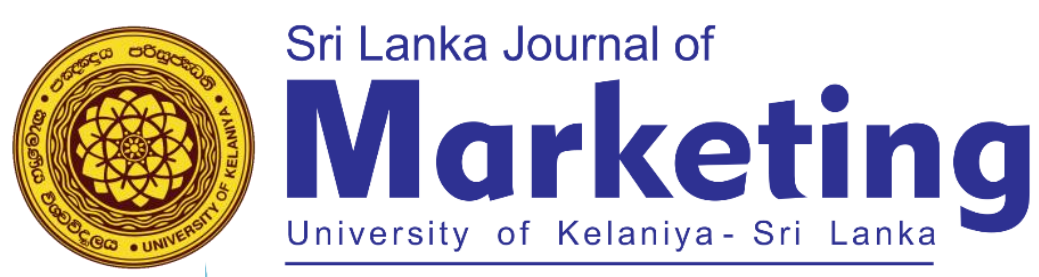

\title{
Assessing the Mediation Role of the Customer Trust On E-Service Quality: Lessons During Covid-19 Pandemic
}

\author{
P.K.A.T.D.R. Gunawardana \\ Department of Management Sciences, Uva Wellassa University of Sri Lanka \\ tgunawardana288@gmail.com \\ P.I.N Fernando \\ Department of Management Sciences, Uva Wellassa University of Sri Lanka \\ imalif@uwu.ac.lk
}

DOI: http://doi.org/10.4038/sljmuok.v7i3.76

\begin{abstract}
Online groceries or e-groceries were highlighted as one of the effective means to avoid personal contacts and maintain social distance during the Covid-19 Pandemic. Thus, this paper focuses on the insight on the impact of e-service quality dimensions and customer satisfaction of e-groceries with the role of customer trust as a mediating variable during the epidemic. A quantitative approach has been adopted where the empirical data gathered from 300 e-grocery shoppers in Western province, Sri Lanka while adopting the multi-stage sampling technique. A field survey was conducted during the first wave of the Covid-19 pandemic during March-June 2020. Regression analysis was the main analysis method whereas the Barron and Kenny mediator analysis and Sobel test were adopted for mediation impact. Findings highlight, e-service quality dimensions strongly impact the customer satisfaction of e-groceries during the Pandemic whereas customer trust partially mediates the e-service quality and customer satisfaction of e-groceries. Implications focused on; (a) e-grocery service providers have to distinct on revamp of customer trust parameters, (b) eservice quality dimensions to enhance the customer satisfaction, customer trust, and (c) attract more customers for e-grocery shopping.
\end{abstract}

Keywords: Covid-19, Customer Satisfaction, Customer Trust, E-Groceries, E-Service Quality

ORCID of authors: P.I.N Fernando. - (iD https://orcid.org/0000-0001-9487-5569

Copyright: This is an open access article distributed under the Creative Commons Attribution License 4.0, which permits unrestricted use, distribution, and reproduction in any medium, provided the original work is properly cited. 


\section{INTRODUCTION}

The e-grocery or Online grocery is one of the significant segments within e-commerce. Accordingly, e-grocery is either a supermarket or grocery store that allows ordering the goods online. With the dawn of the Covid-19 outbreak, Sri Lankan e-groceries have flowed and it becomes an opportunity for egrocers and customers have encouraged online purchasing as an alternative to the physical store. egroceries are a rising movement for marketers to promote their products in a wide geographical area and highlight as the most effective way to avoid personal contacts and keep social distancing. According to the Department of Census and Statistics, the internet penetration rate of Sri Lanka is stood at $47 \%$ in January (2020) and internet usage has been growing in the past years, by enhancing the use of the internet for shopping goods and services simultaneously. The e-grocery concept is still novel to the Sri Lankan e-business industry and customers are slowly adopting to use the e-groceries. Thus, online retail space in Sri Lanka is currently estimated at US\$ 85-90 million and online retail penetration is less than one percent (Asia Securities Report,2019). With the surge of e-groceries, customers are seeking service quality through e-groceries same as the physical grocery store. In this context, electronic service quality has emerged as an area of strategic importance. Moreover, to influence customers' online shopping experience and customer satisfaction, identifying and understanding the e-service quality dimensions is more important (Yang, 2001). As e-groceries have grown during the outbreak, e-service quality has to turn out to be an increasing factor to survive within the online grocery businesses.

\section{RESEARCH PROBLEM}

The e-service quality concept is considered an emerging area of research that has strategic importance for businesses to address the customers in the electronic marketplace (Asadpoor,2017). Online customers expect a high or equal level of service quality similar to the traditional grocery customers (Lee \& Lin, 2005), thus stressing the vital role of e-service quality to marketers. Related studies on eservice quality have been researched on the SERVQUAL scale to measure services in various online contexts such as internet retail (Santouridis, 2009; Akter, 2016; Kaur, 2018) and electronic banking (Zavareh et al., 2012), and e-service quality in e-groceries (Mortimer et al., 2016). Moreover, customers are seeking service quality from e-grocery stores the same as the traditional physical grocery stores. To gain a competitive advantage and to enhance customer satisfaction from the e-services, businesses have to pay more attention to the e-service quality. Hence, the e-service quality concept is still a fascinating researchable area, as well the e-grocery is a somewhat novel experience to the Sri Lanka context, thus identified as research gaps.

Therefore, research questions and have been developed as, (a) What kind of an impact exists with eservice quality dimensions on customer satisfaction of e- groceries and (b) What kind of an impact is explored in customer trust as a mediator between e-service quality dimensions and customer satisfaction of e-groceries. 
Align with the research gap, objectives of the paper have been developed;

- Investigate the impact of e-service quality dimensions on customer satisfaction of e-groceries

- Assess the mediator impact of customer trust as a mediator between e-service quality dimensions and customer satisfaction of e-groceries

The paper targets the time period of the first wave of the Covid-19 pandemic during March- June 2020, whereas the e-groceries have been massively promoted due to safety and social distancing.

\section{LITERATURE REVIEW}

The authors conducted a comprehensive literature review by targeting vital scholarly articles on the concepts of e-groceries and e-service quality among the online platforms.

\subsection{E-Service Quality}

Surround all aspects of customer's interactions with a web site refer as the e-service quality (Parasuraman et al., 2005). Electronic service quality or e-service Quality is un-dimensional although there are many dimensions published by the researchers and on the realization of electronic service quality and customer satisfaction (Zithamal, 2002). In past decades most of the researches has been focused on service quality in the traditional service contexts, nevertheless, in recent few years, the interest in e-quality also increased due to the well-acknowledged relationship between service quality and performance of the business (Rowley, 2006). Zeithamal (2002) identified that the effectiveness and the efficiency of shopping, purchasing goods, and delivery time facilitate by a website as the e-service quality whereas, the marketers need to understand what drives the customers' perception and evaluate e-service to provide value and quality service via online (Parasuraman et al.,2005).

\subsection{E-service Quality Dimensions}

There are ten dimensions introduced as reliability, responsiveness, competence, access, courtesy, communication, credibility, security, understanding the customers, and tangibility (Parasuraman, 1988; Zeithamal, 2002). Later on, Parasuraman, (1988) modified the variables to five categories as tangibility, reliability, responsiveness, assurance, and empathy or SERVQUAL. Nevertheless, these dimensions may not be able to anticipate to imprison all the subtitles of the estimation of commercial website's service quality (Zeithamal et al., 2005). 
Table 1: Dimensions of electronic service quality

\begin{tabular}{ll}
\hline Scholar & Dimensions \\
\hline Lee \& Lin, (2005) & $\begin{array}{l}\text { Reliability, Responsiveness, Website design, Trust, } \\
\text { personalization }\end{array}$ \\
\hline Madu \& Madu, (2002) & $\begin{array}{l}\text { Performance, Features, Structure, Credibility, Aesthetic, } \\
\text { storage capacity, Serviceability, Security, System Integrity, } \\
\text { Trust, Responsiveness, Differentiation, Customization, } \\
\text { Assurance }\end{array}$ \\
\hline Meuter et al.,(2000) & $\begin{array}{l}\text { Efficiency, Flexibility, Security, Personalization, } \\
\text { Convenience }\end{array}$ \\
\hline Long \& McMellon, (2004) & $\begin{array}{l}\text { Reliability, Responsiveness, Assurance, Empathy, } \\
\text { Tangibility, Communication }\end{array}$ \\
\hline Iliachenko, (2006) & $\begin{array}{l}\text { Reliability, Efficiency, Responsiveness, Credibility, } \\
\text { tangibility, Communication }\end{array}$ \\
\hline
\end{tabular}

\subsection{Customer Satisfaction}

Scholars mention that customer satisfaction provides an advantage to the business organizations to enhance profitability, influence customer repurchase intention (Kitapci et al., 2013) whereas satisfaction occurs when customers get what they expect from a service or commodity (Kotler, 2003). Customer satisfaction is defined by Kotler (2000) as the customer expectation and the positive and negative feelings arising from comparing the product's perceived performance. Thus, satisfaction occurs once compared the service is actually received with what customers expect from that service (Kotler \& Keller, 2006). Szymanski \& Hise, (2000) indicates that online shopping convenience, product information, and product offerings, website design, and financial security are affected by customer satisfaction in the e-commerce context, thus highlighting the online platforms. Hsu (2008) introduced perceived value and trust significantly affect customer satisfaction and suggested American Customer Satisfaction Index (ACSI) evaluate online customer satisfaction. Within the Sri Lankan context, customer satisfaction was addressed by scholars by getting different contexts, as ethnocentrism (Costa et al., 2018), visual merchandising (Rathnayake and Fernando, 2017), and purchasing behavior on premium products and Ayurvedic products (Padamali and Fernando, 2016; Pathmaperuma and Fernando, 2018 ).

\subsection{E-service Quality and Customer Satisfaction}

Electronic service quality is an attitude towards the excellence of the service and customer satisfaction is associated with a specific transaction (Parasuraman et al., 1988) whereas, the satisfaction will be decided on the quality of the service provided by the service provider (Lee et al., 2000). The interrelation between customer satisfaction and electronic service quality is an argument concept 
whereas the e-service quality is preceding customer satisfaction (Oliver, 1980). Electronic service quality positively impacts consumer satisfaction and attitude towards websites (Carlson \& Ocass, 2010), and to survive within the rivalry industry competition, marketers need to pay attention to e-services to attract more prospective customers and retain the current customers (Zeithmal, 2002). The customer intention to shop in the future could be influenced by the service quality of online stores as well the eservice quality can attract potential customers (Cai \& Jun 2003).

\subsection{E-service Quality Dimensions and Customer Satisfaction}

To reinterpret the e-service quality clear definitions of the dimensions are required by electronic service providers (Zavareh, et al., 2012) since the dimensions of e-service quality affect customer satisfaction and overall service quality (Lee \& Len, 2005). Accordingly, there doesn't exist any exact number of eservice quality dimensions when evaluating e-service quality (Zeithaml \& Parasuraman, 2000; Sirinivasan et al., 2002). Whereas most scholars view e-service quality dimensions as an antecedent of e- customer satisfaction (Szymanski \& Hise, 2000). Due to the lack of financial security, privacy, lack of human contact, and poor design of the interface of the website could reduce the customer satisfaction on e-service quality (Meuter et al., 2000). Customer satisfaction can be anticipated through the website quality dimensions such as reliability of the information, response time, transaction capability, and website attributes. Thus, website service quality, service convenience, and risk are affected by e-service discovered that consumers' satisfaction and intention (Kim \& Stoel, 2004; Zhang \& Prybutok, 2005). Hence, the Hypothesis 1 (H1) has been developed;

H1: e- service quality dimensions have a positive significant effect on customer satisfaction of $e$ groceries

\subsubsection{Reliability}

Reliability is the capability of the websites to fulfill the customer's orders correctly, deliver properly, and keep personal information secure (Parasuraman et al., 1988; Janda et al., 2002; Kim \& Lee, 2002). Reliability has been mostly emphasized by information technology-based services (Lee et al.,2005) whereas, to provide a reliability service, the marketer should provide the service as promised and reliably (Al-Dmour, 2005). Correct technical recruitments and promised services such as the delivery of customer orders, delivery time, advertising, and product information should include in reliable eservice (Parasuraman et al., 2005).

\subsubsection{Efficiency}

Efficiency could be defined as the ability to access and use the web sites easily and quickly (Mummalaneni \& Meng, 2009), and ease of use web site and no need much of information to answer 
customer interventions (Zeithaml, 2005). Further, to provide an efficient e-service, the website should be designed properly and appropriately (Parasuraman, 2005). Electronic service efficiency is differing from traditional service efficiency due to the traditional services are based on the service provider's skills, knowledge, and ability (Al-Dmour, 2005) and are later defined by different dimensions. To provide superior e-service quality to customers, the organization should ensure order accuracy, delivery timeliness, complete delivery conditions, and order fulfillment (Rita et al., 2019).

\subsubsection{Information}

Valuable information and high-quality content of the online stores' website help to improve the satisfaction of the shoppers (Kim \& Lim, 2001). Further, there should be a provision for additional and delivery time information, detailed-description of the exterior of products and all that information should be easy to understand (Cho \& Park, 2001) as well the provided information should be understandable, reliable, well organized, and presented attractively (Yang, 2007), thus, customers should be allowed to interact with the websites to receive tailored information (Kim \& Stoel, 2004). There is a significant positive impact of information and user interface quality of e-commerce on customer satisfaction according to the determinants of the B2C e-commerce customer satisfaction (Eid, 2011).

\subsubsection{Responsiveness}

Responsiveness is defined as (a) providing instructions for using the website and assisting when problems occur in the service and the degree of assistance received while searching the information and guidance for taking the service (Griffiths \& Brophy, 2005), (b) meeting all the customer requirements and respond quickly for service requests and (c) desire to help the customer (Al-Bakri,2005). According to scholars (Parasuraman et al.,1988), responsiveness is how frequently online stores voluntarily provide electronic services that are important for customers such as customer inquiries, information retrieval, and navigation speed and prompt response for the inquiries expected by the customers from the online stores (Liao \& Cheung, 2002).

\subsubsection{Assurance}

Assurance refers to the security of using online financial services both online customers and other customers worry about the acquisition and dissemination of personal data through websites (Lociacono et al., 2000; Montoyo et al., 2000). To assess the service quality of the online store, privacy and website security both are vital, whereas the customers pay attention to whether the website would protect the transactions against frauds (Rita et al., 2019). Thus, security in a variety of payment options such as credit card and PayPal should be guaranteed against credit card fraud, whereas the security of the transaction should ensure in online businesses (Limbu et al, 2011). 


\subsubsection{Customer Trust}

Customer trust is interconnected with the information provided to online consumers (Zeithaml et al., 2002). Scholars have described different dimensions and indicators for the concept of customer trust. among them, Trust is dealing with the integrity: honesty and keeping the promise by the suppliers, competence: supplier's capability to accomplish what customer needs, predictability: behavioral consistency of suppliers, and benevolence: supplier's motivation and caring to act like the customer's interest (Wang et al., 2006). Another indicator for customer trust highlights, creating confidence in customers, sending products as promised by suppliers, returning back when products get damaged, treats honestly in every transaction (Sundaram et al., 2017). Lack of trust in business-to-consumer services is one of the main reasons for unwillingness to buy the products through the internet (GrabnerKraeuter, 2002). An online trust may depend on the previous experiences that customers received from online stores such as service quality, a sign from the website, or the others' recommendations (Codina $e t$ al., 2011).

Thus, the Hypothesis 2 and 3 (H2 and $\mathrm{H} 3$ ) and has been developed;

H2: e-service quality dimensions have a positive significant effect on trust H3: Trust has a positive effect on customer satisfaction of e-groceries

\section{6. e-service Quality Dimensions, Customer Trust and Customer Satisfaction}

Conveying the trustworthiness of the website and the system to consumers by using the quality dimensions of the e-services is the main way to represent customer trust in online stores (Kundu \& Datta, 2015). Further, Customer Trust has been linked with online customer satisfaction in the ecommerce context (Santouridis, 2009) and the development of trust can depend straightly on customer satisfaction (Singh \& Sirdeshmukh, 2000). Gefen, (2000) applies the SERVQUAL model to examine the impact of e-service quality dimensions on customer trust and identifies dimensions as tangibility, empathy, assurance, reliability, and responsiveness, which have a significant impact on customer trust. Moreover, e-service quality dimensions of user-friendliness and efficiency also have a significant effect on customer trust (Kundu \& Datta, 2015). Thus, there is a positive relationship between customer satisfaction and customer trust (Ganesan \& Hess, 1997) whereas online customer satisfaction could be improved significantly through e-service quality (Kassim \& Abdullah, 2010). Further, customers are ready to accept any service provided by the web hosting service provider if the customer feels the trust since the e-service quality shows a direct positive and significant effect on customer trust (Anderson \& Srinivasan, 2003; Mukherjee \& Nath, 2007; Chenet et al., 2010). As scholars pointed out, the long-term relationship with the customers would create Trust (Mukherjee \& Nath, 2007).

Hence, the Hypothesis 4 (H4) has been developed; 
H4: There is a relationship between e-service quality dimensions and customer satisfaction of egroceries through the customer trust.

\section{7. e-grocery Shopping}

Due to the perishability and variability of the products and frequency of shopping, e-grocery shopping is different from other types (Lynda et al., 2016). General online shopping differs from online grocery shopping where the e-grocery shoppers report the convenience and ease of use as positive drivers of adoption to e-groceries (Sin et al., 2002) although, products that counted as to see, touch, and smell categories such as meat, fresh products and bake goods (Huang \& Oppewel, 2006) are considered as a challenge in online grocery environment (Citrin et al., 2003). Customers may resist risk and that product purchased may slump prior to the delivery even though the quality and freshness of goods can be claimed online (Tsiros \& Heilman, 2005).

Thus, the Conceptual model have been developed by adopting the past scholars works.

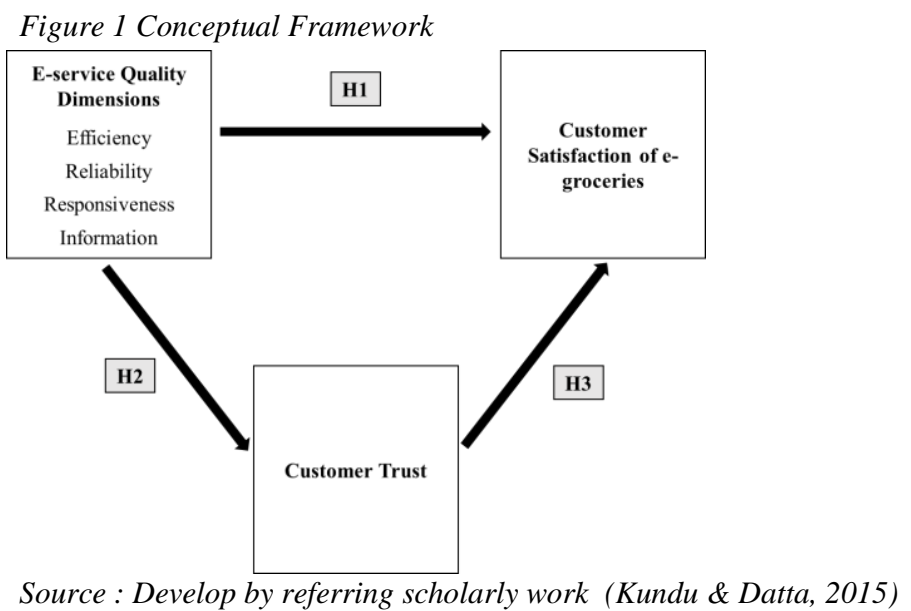

\section{METHODOLOGY}

\subsection{Population and Sample}

The research is measuring the impact of e-service quality dimensions on customer satisfaction of egroceries in Sri Lanka. Therefore, all the Sri Lankan customers' who consume goods via online groceries which can be either supermarkets or other groceries that allow ordering goods online are considered as the population of this research. According to the report of the fitch rating of the world bank (2017), the modern online grocery penetration is about $18 \%$ in Sri Lanka. hence, e-grocery shoppers in the Colombo district have been selected as the sample based on the highest percentage distribution of Internet (44.9\%) and e-mail (20.4\%) and the household population (2018) compared to other districts (Department of Census and Statistics of Sri Lanka, 2018). As a representative sample, three Divisional Secretariats were selected, (1) Colombo, (2) Dehiwala, and (3) Kotte, based on a high 
population density of more than 20,000 square miles in Colombo District and higher availability of egroceries. The sample has been calculated under a confidence level of $95 \%$ and confidence interval.

\subsection{Sampling Technique and Framework}

The probability sampling technique has been adopted as the sampling technique through multistage sampling, which is divide a large population into stages to make the sampling process more reliable and practical. In order to categorize the sample, a multistage sampling technique was used which combines stratified sampling and simple random sampling.

Figure 2 : Sampling frame

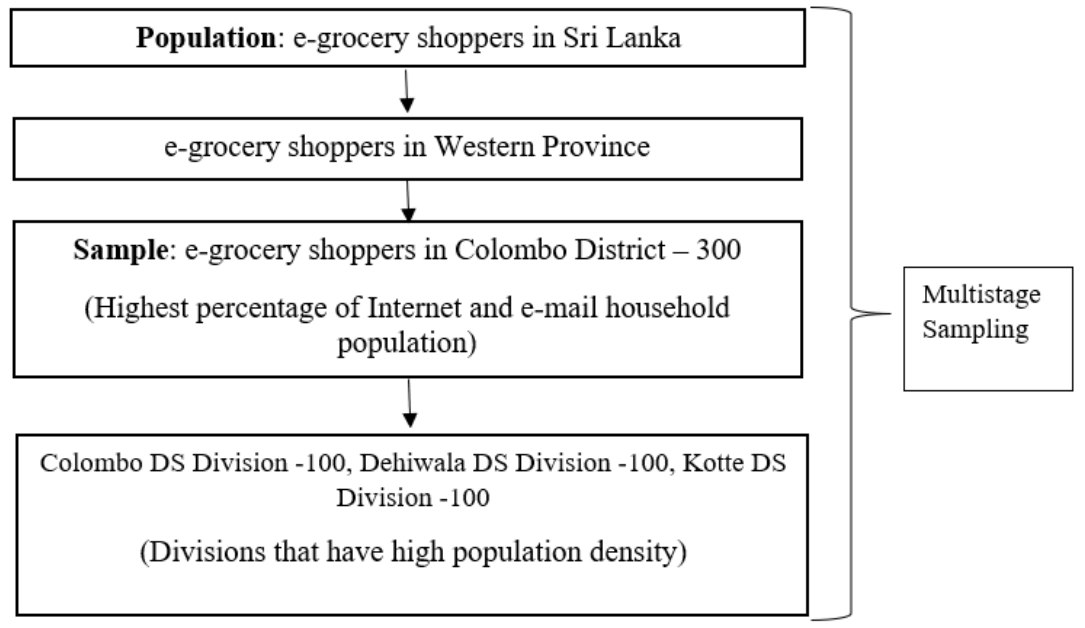

\section{DATA COLLECTION}

The questionnaire was administered to the data collection which was consisted of close-ended multiplechoice questions and scale questions. All the dimensions used to measure the variables in the proposed model are described in the operationalization. A pilot test was conducted by using 30 e-grocery shoppers randomly selected by the sample and the reliability of the questionnaire was tested by the Cronbach's Alpha value based on that pilot survey.

Table 2 Cronbach's Alpha Reliability Test

\begin{tabular}{|l|l|l|}
\hline \multicolumn{1}{|c|}{ Variable } & \multicolumn{1}{|c|}{ Dimension } & \multicolumn{1}{c|}{ Cronbach's Alpha } \\
\hline E-service quality dimensions & Efficiency & 0.860 \\
\hline & Information & 0.727 \\
\hline & Reliability & 0.743 \\
\hline & Assurance & 0.793 \\
\hline Customer Trust & Responsiveness & 0.736 \\
\hline Customer Satisfaction & & 0.787 \\
\hline
\end{tabular}

Source: SPSS output from field information 
Table 3 Reliability Statistics for Overall model

\begin{tabular}{l|l|l}
\hline \multicolumn{1}{c|}{ Cronbach's Alpha } & $\begin{array}{c}\text { Cronbach's Alpha Based on Standardized } \\
\text { Item }\end{array}$ & No of Items \\
\hline .749 & .747 & 30 \\
\hline \multicolumn{2}{l|}{ Source: SPSS output from field information }
\end{tabular}

\section{OPERATIONALIZATION}

To measure the theoretical constructs indicators have developed and operationalization of the study done according to the variables that have identified in the conceptual framework.

Table 4: Operationalization of variables

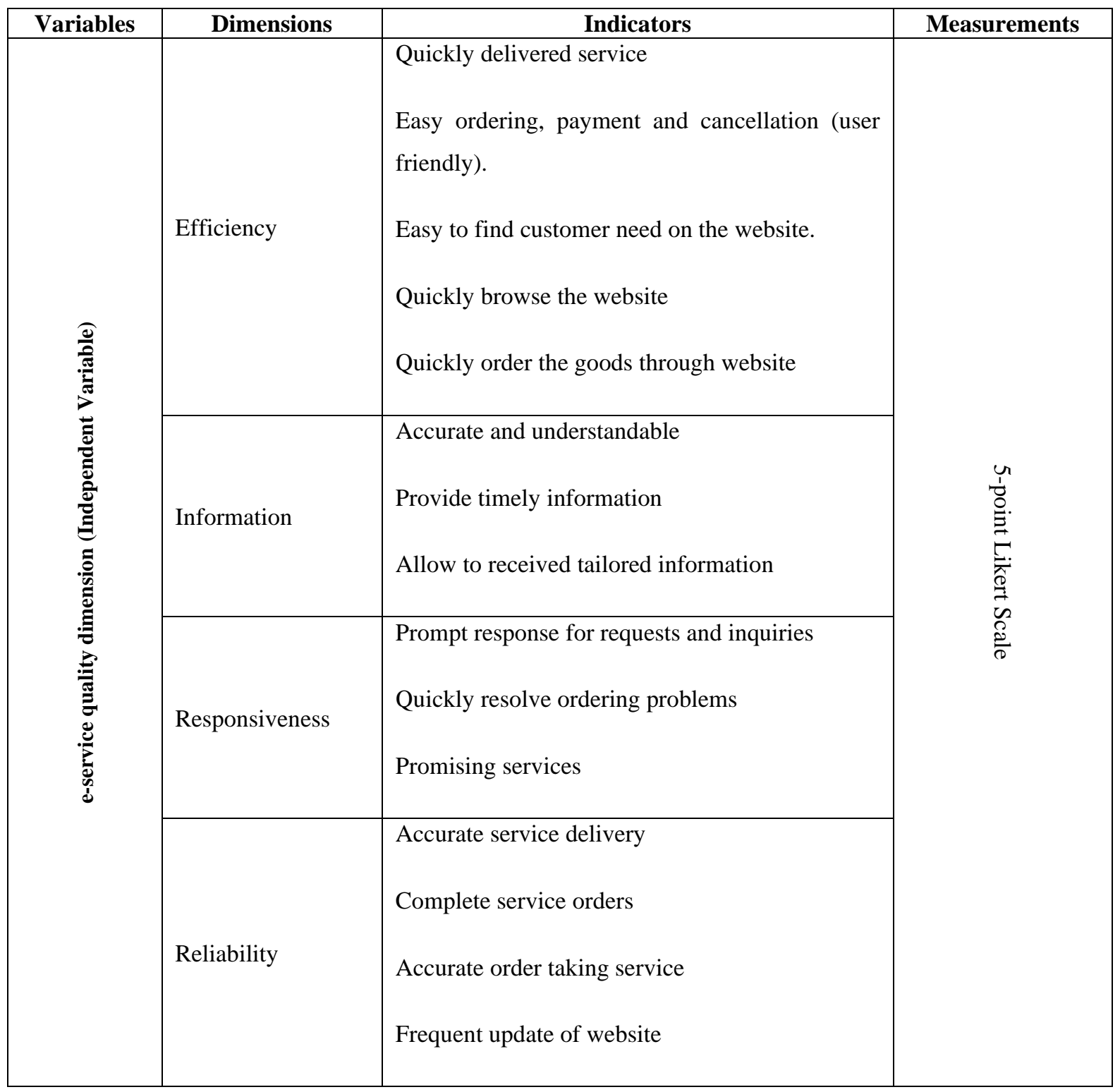




\begin{tabular}{|c|c|c|c|}
\hline & Assurance & $\begin{array}{l}\text { Secure customer information } \\
\text { No customer information provides to others } \\
\text { Secure credit card information }\end{array}$ & \\
\hline 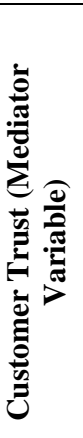 & $\begin{array}{l}\text { Taking care } \\
\text { Sending pr } \\
\text { Return bacl } \\
\text { Treats in ar } \\
\text { Create conf }\end{array}$ & $\begin{array}{l}\text { customers } \\
\text { romised } \\
\text { damaged } \\
\text { ay in every transaction } \\
\text { customers }\end{array}$ & \multirow{2}{*}{ 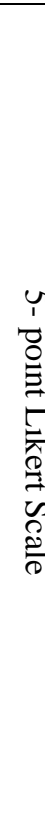 } \\
\hline 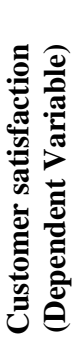 & $\begin{array}{l}\text { Satisfaction } \\
\text { Recommen } \\
\text { I regularly } \\
\text { E-grocery s }\end{array}$ & $\begin{array}{l}\text { ocery shopping } \\
\text { rocery service } \\
\text { providing the expected service }\end{array}$ & \\
\hline
\end{tabular}

\section{DATA ANALYSIS}

\subsection{Descriptive Statistics}

The descriptive techniques were used to recognize the demographic characteristics of e-grocery customers in Sri Lanka. Table 5 depicts summary statistics of the sample respondents.

Table 5 Summary of Findings of Descriptive Statistics

\begin{tabular}{ll}
\hline \multicolumn{1}{c}{ Descriptive } & \multicolumn{1}{c}{ Main Finding } \\
\hline Distribution of age & Most e-grocery users aged between 35-44 years \\
\hline Distribution of gender & Female customers mostly use e-groceries \\
\hline Distribution of occupation & Government employees mostly used e-groceries \\
\hline Hours spent on internet & $\begin{array}{l}\text { Most of the e-grocery uses spent on internet about 1-3 hours per } \\
\text { day }\end{array}$ \\
\hline Frequency & Frequency of 1-3 weeks during the pandemic \\
\hline Amount spend for e-grocery & Spend between Rs.3000-5000 for e-groceries \\
\hline Most frequently used e-grocery & $\begin{array}{l}\text { Most customers order via Keells Super Online Grocery and } \\
\text { Cargills Online Grocery }\end{array}$ \\
\hline e-grocery delivery time & $\begin{array}{l}\text { Most of e-grocery service providers deliver goods within 24 } \\
\text { hours }\end{array}$ \\
\hline SOurce: $P S S$ output from fied suvey
\end{tabular}

Source: SPSS output from field survey 


\subsection{Correlation Analysis}

The correlation between the independent variable e-service quality dimensions and the dependent variable customer satisfaction is 0.649 (64.9\%), which implied that there was a strong positive relationship between e-service quality dimensions and customer satisfaction of e-groceries. Correlation between the independent variable; e-service quality dimension and mediating variable; Customer Trust counts as 0.704 and comprehended there is a strong positive correlation. Further, mediating variable; Customer Trust and the dependent variable Customer Satisfaction of e-groceries counts as 0.664 and shows a strong positive linear relationship. The P-value was at zero level $(0.000<0.05)$ thus, rejecting the null hypothesis (H0) and accepting the alternative hypothesis (H1) at a 95\% confidence level. All the null hypotheses were rejected and H1, H2, H3, and H4 were accepted. Furthermore, there is a strong positive relationship between the dependent variable, independent variable, and mediator variable.

Table 6: Regression analysis of e-service quality and Customer Satisfaction

$$
\mathrm{CS}=0.216+0.866 \mathrm{ESQD}+\varepsilon
$$

Source: SPSS output from field information

According to the regression equation, the constant value is 0.216 and it implies that the value Customer Satisfaction when the e-service quality is equaled to the zero level. Moreover, the coefficient of eservice quality dimensions is 0.866 and implies when e-service quality was increased by one unit, Customer Satisfaction increase by 0.866 . Thus, suggested that there is a positive relationship between both variables

\subsection{Model Summary}

Source:

Table 7. Model summary for linear regression analysis

field

\begin{tabular}{lllll} 
Figure & $\mathrm{R}$ & R Square & Adjusted R Square & $\begin{array}{l}\text { Std. Error of } \\
\text { Estimate }\end{array}$ \\
\hline Value & $.649^{\mathrm{a}}$ & .421 & .419 & .42435 \\
\hline
\end{tabular}

information

According to the linear regression model summary, the R2 $=0.421$ and implies $42.1 \%$ of the total variation of customer satisfaction is explained by the e-service quality dimension. Further, due to the residuals, approximately $58 \%$ of the total variation in customer satisfaction is unexplained by the linear regression model by highlighting other variables which have not been included in the original model. Due to the unexplained variation being greater than the explained variation the model is fitted with high residuals. Moreover, the adjusted R2 value was 0.419 and it implies how data was derived from the fitted line of regression and moreover, the standard error of the estimate was 0.42435 . 


\subsection{Overall Significance of the Model}

Table 8: ANOVA

\begin{tabular}{lllllll}
\hline Model & & Sum of Squares & df & Mean Square & F & Sig. \\
\hline & Regression & 38.978 & 1 & 38.978 & 216.456 & $.000^{\mathrm{b}}$ \\
& Residual & 53.662 & 298 & .180 & & \\
& Total & 92.641 & 299 & & & \\
\hline
\end{tabular}

a. Dependent Variable: Customer satisfaction

b. Predictors: (Constant), E-service quality dimensions

Source: SPSS output from field information

The model is overall significant at a $95 \%$ significance level (P-value is 0.000$)$. Further, the $\mathrm{F}$ value of this study is 216.456 although greater than the F table value, thus the model is significant.

\subsection{Mediator Analysis}

Table 9. Summary table of mediator analysis

\begin{tabular}{lllll}
\hline Path & $\begin{array}{l}\text { B (unstandardized } \\
\text { coefficient) }\end{array}$ & Standard Error & $\begin{array}{l}\beta \text { (Standardized } \\
\text { coefficient) }\end{array}$ & P-value \\
\hline $\mathrm{c}$ & .866 & .590 & .649 & .000 \\
\hline $\mathrm{a}$ & .590 & .034 & .704 & .000 \\
\hline $\mathrm{b}$ & .743 & .048 & .664 & .000 \\
\hline $\mathrm{c}$ & .460 & .064 & .411 & .000 \\
\hline Source: SPSS output from field survey & & &
\end{tabular}

Source: SPSS output from field survey

According to Table 9, all the four paths of the mediator model are significant with coefficients of 0.866 , $0.590,0.743,0.460$ at the 0.05 significance level. According to the unstandardized coefficient between e-service quality dimensions and customer satisfaction of e-groceries identified that there is a strong positive relationship between the two variables and it implies a coefficient of 0.866 at the $p$-value of 0.000 and significant at 0.05 level. Hence, it can be concluded, without having a mediator there is a strong positive relationship between independent and dependent variables. The unstandardized coefficient between e-service quality dimensions and customer trust was 0.590 and it suggests a weak positive relationship between the independent variable and mediator variable.

Moreover, the unstandardized coefficient between customer trust and customer satisfaction of egroceries was 0.743 which illustrates there is a strong positive relationship between the mediator variable and dependent variable. When analyzing the independent variable and mediating variable in predicting the dependent variable there is a statistical significance relationship $(\mathrm{P}<0.05)$ between variables according to the supported data. Its implied unstandardized coefficient is 0.460 . Hence, there is a weak positive relationship between variables and the mediator is in the model. Therefore, all the paths are significant and when compared the $\mathrm{c}$ path and c' path there is a significant difference between the unstandardized coefficient of the two paths. 


$$
\text { c path }-c^{\prime} \text { path }=0.866-0.460=0.406
$$

Based on the above difference, when the mediator is in the model, the effect of the independent variable on the dependent variable is reduced. Unstandardized coefficient difference of 0.406 implies that customer trust partially mediates the relationship between e-service quality dimensions and customer satisfaction of e-groceries at a 0.05 significance level.

\subsection{Sobel Test}

Figure 3. Sobel Test

\begin{tabular}{|c|c|c|c|c|c|}
\hline & Input: & & Test statistic: & Std. Error: & p-value: \\
\hline$a$ & 0.590 & Sobel test: & 11.55129759 & 0.03794985 & 0 \\
\hline$b$ & 0.743 & Aroian test: & 11.54063116 & 0.03798492 & 0 \\
\hline$s_{a}$ & 0.034 & Goodman test: & 11.56199365 & 0.03791474 & 0 \\
\hline$s_{b}$ & 0.048 & Reset all & & Calculate & \\
\hline
\end{tabular}

Source: http://quantpsy.org/sobel/sobel.htm

$\mathrm{Sab}=\sqrt{ }(\boldsymbol{S} \boldsymbol{b} \cdot \boldsymbol{a}) 2+(\boldsymbol{S} \boldsymbol{a} \cdot \boldsymbol{b}) 2$

Sobel's SE $=\sqrt{ }(\boldsymbol{S} \boldsymbol{b} . \boldsymbol{a}) 2+(\boldsymbol{S a} . \boldsymbol{b}) 2=0.03794$

According to the test statistics, the value of the Sobel test is 11.55 at a $95 \%$ significant level $(<0.5)$, therefore, mediation of customer trust is extremely statistically significant.

Sobel Test Value $=11.55129$ and Portion of $(\mathrm{X} \rightarrow \mathrm{Y})$ due to $\mathrm{M}=\left(\mathrm{c}-\mathrm{c}^{\prime} / \mathrm{c}\right)=0.468822$

The results of the Sobel test imply that $46.88 \%$ controllability is with the mediating variable customer trust to the relationship between e-service quality dimensions and customer satisfaction of e-groceries.

\section{CONCLUSION}

This research enlightens the knowledge base of the e-service quality of e-groceries in the Sri Lankan context. Health recommendations to contain the current epidemic of Covid-19 is to avoid personal contacts and maintain the social distancing whereas e-shopping emerged. Therefore, e-services as online groceries will have reduced the human-movements and increased the time spent at home. Customer trust become a more influencing factor for e-services and the payment methods such as credit cards and debit cards would enhance the trust between customers during this Covid-19 pandemic.

The research findings reveal that most of the customers (84.3\%) tend to use e-groceries after the Covid19 pandemic and implies although the e-grocery concept is not new to the world, in the Sri Lankan context this becomes surged with the initiation of the pandemic. Accordingly, customers were satisfied with the delivery time of the e-grocery service providers as most e-grocery services deliver goods within 
24 hours but also there were some service providers who take more than 2 days. The regression impact of the e-service quality dimensions on customer satisfaction of e-groceries is high (0.866) with a significant $\mathrm{P}$-value, and indicates e-service quality dimensions have an influence on customer satisfaction of e-groceries. Other than that e-service quality of e-groceries has a major influence on customer trust with a high mediation effect on customer satisfaction Moreover, when considering the e-service quality dimensions, information and efficiency are major two influencers for customer satisfaction of e-groceries whereas all dimensions have low regression weight with $\mathrm{P}$ values. Therefore, e-grocery service providers should take more care of (a) efficiency of the service, providing accurate and timely information, providing promised service to their customers to fulfill the requirement of customers, maintaining the personal privacy of transactional information, and responsive for the customer requirements and complaints. Further, a mediation impact exists between the customer trust, e-service quality dimensions, and customer satisfaction of e-groceries.

\subsection{Managerial Implications}

The proposed conceptual model provides exhaustively the factors necessary to achieve high e-service quality that will significantly impact customer satisfaction and customer trust. As the e-service quality dimensions' influence customer trust significantly, e-grocery service providers must understand the importance of improving those dimensions to retain the customers and attract new customers for online grocery shopping. Moreover, e-grocery service providers can be able to formulate and implement strategic plans to improve the e-service quality and e-grocery service providers can get a better understanding of the dimensions of electronic service quality and how customers assess the quality of the service of e-groceries through customer trust.

\section{Following implications were highlighted by the study;}

- Delivery delays and not-return the damaged: e-grocery service providers have to create a mechanism to deliver more effective service to the customers if not customers trust might decay

- Trustworthy payment system with combined online banking: customers are hesitating to provide their credit card details and personal information due to trust issues

- Prompt response for inquiries and order problems: e-grocery service providers have to build a standard mechanism and policies to providing better responsiveness to the customers to build up customer trust and customer satisfaction regarding the e-grocery shopping

- Frequent website updates: reliability of the service quality can be reduced thus the websites to be frequently updated

- Government interventions via legal policy formulations: enhance the customer trust in e-service quality 


\subsection{Direction for future researches}

Throughout this study assessed the effect of e-service quality dimensions on customer satisfaction with mediating effect of customer trust. Therefore, future researchers could focus on other external environmental factors that can influence the online business context in Sri Lanka. Future research studies can be conducting a study on e-groceries with different variables and mediators such as customer attitude, purchase intention, and behavior. Moreover, a smaller number of people are using e-grocery shipping normally, therefore, future research suggests that find out what is the reason for that and cultural difference for online grocery shopping.

\section{REFERENCES}

Anderson, R. E. \& Srinivasan, S. S.(2003). e-Satisfaction and e-Loyalty: A contingency framework. Psychology and Marketing, 20(2), 123-138. https://doi.org/10.1002/mar.10063

Barnes, S. J., \& Vidgen, R. T. (2002). An integrative approach to the assessment of e-commerce quality. $J$. Electron. Commerce Res., 3(3), 114-127.

Baron, R. M., \& Kenny, D. A. (1986). The moderator-mediator variable distinction in social psychological research: Conceptual, strategic, and statistical considerations. Journal of Personality and Social Psychology, 51(6), 1173.

Brengman, M., \& Geuens, M. (2002). Profiling Internet users based on their propensity to adopt online shopping. ACR Asia-Pacific Advances.

Chenet, P., Dagger, T. S., \& O'Sullivan, D. (2010). Service quality, trust, commitment and service differentiation in business relationships. Journal of Services Marketing, 24(5), 336-346. https://doi.org/10.1108/08876041011060440

Chiou, J. S., \& Droge, C. (2006). Service quality, trust, specific asset investment, and expertise: Direct and indirect effects in a satisfaction-loyalty framework. Journal of the Academy of Marketing Science,34(4),613-627. https://doi.org/10.1177/0092070306286934

Citrin, A. V., Stem, D. E., Spangenberg, E. R., \& Clark, M. J. (2003). Consumer need for tactile input: An internet retailing challenge. Journal of Business Research, 56(11), 915-922. https://doi.org/10.1016/S01482963(01)00278-8

Codina, C., Pascalis, O., Mody, C., Toomey, P., Rose, J., Gummer, L., \& Buckley, D. (2011). Visual advantage in deaf adults linked to retinal changes. PLOS ONE, 6(6), 10-15. https://doi.org/10.1371/journal.pone.0020417

Dinesha Costa Y.K.H., Fernando P.I.N. and Upeksha A.S.Yapa (2018), The effect of ethnocentrism and patriotism on consumer preference, Journal of Management and Tourism Research, Uva Wellassa University, I (2) , 120

Fassnacht, M., \& Köse, I. (2007). Consequences of web-based service quality: Uncovering a multi-faceted chain of effects. Journal of Interactive Marketing, 21(3), 35-54. https://doi.org/10.1002/dir.20084

Ganesan, S., \& Hess, R. (1997). Dimensions and Levels of Trust: Implications for commitment to a relationship. Marketing Letters, 8(4), 439-448. https://doi.org/10.1023/A:1007955514781 
Gefen, D. (2000). e-commerce: The role of familiarity and trust. Omega, 28(6), 725-737. https://doi.org/10.1016/S0305-0483(00)00021-9

Grabner-Kraeuter, S. (2002). The role of consumers' trust in online-shopping. Journal of Business Ethics, 39(1), 43-50. https://doi.org/10.1023/A:1016323815802

Hong, S. N., \& Caire, G. (2012). Antenna and user selection for a cloud base station with (Reverse) compute and forward. 2012 IEEE Globecom Workshops, GC Wkshps 2012, 30(1), 261-266. https://doi.org/10.1109/GLOCOMW.2012.6477580

Jun, M., Yang, Z., \& Kim, D. S. (2004). Customers' perceptions of online retailing service quality and their satisfaction. International Journal of Quality and Reliability Management, 21(8), 817-840. https://doi.org/10.1108/02656710410551728

Kassim, N., \& Asiah Abdullah, (2010). The effect of perceived service quality dimensions on customer satisfaction, trust, and loyalty in e-commerce settings: A cross cultural analysis. Asia Pacific Journal of Marketing and Logistics, 22(3), 351-371. https://doi.org/10.1108/13555851011062269

Kim, M. J., Chung, N., \& Lee, C. K. (2011). The effect of perceived trust on electronic commerce: Shopping online for tourism products and services in South Korea. Tourism Management, 32(2), 256-265. https://doi.org/10.1016/j.tourman.2010.01.011

Kundu, S., \& Datta, S. K. (2015). Impact of trust on the relationship of e-service quality and customer satisfaction. EuroMed Journal of Business, 10(1), 21-46. https://doi.org/10.1108/EMJB-10-2013-0053

Mackinnon, D. P., Fairchild, A. J., \& Fritz, M. S. (2007). NIH Public Access: Mediation Analysis. Апnи Rev Psychology, 58(Hebb 1966), 593-614. https://doi.org/10.1146/annurev.psych.58.110405.085542.Mediation

Mukherjee, A., \& Nath, P. (2007). Role of electronic trust in online retailing: A re-examination of the commitment-trust theory. In European Journal of Marketing (Vol. 41, Issues 9-10). https://doi.org/10.1108/03090560710773390

Parasuraman A., Zeithaml V.A \& Malhothra A., (2005). ES-QUAL: A multiple-item scale for assessing electronic service quality. Journal of Service Research, 7(3), 213-233.

Pathmaperumna C.R. and P.I.N. Fernando (2018). Factors affecting on consumer purchasing behavior of Ayurvedic skin care products: A study of female consumers in Colombo District of Sri Lanka, Journal of Management Matters , University of Rajarata, 5(1),13-20

Padamali G.M.P and P.I.N Fernando (2018). Product attributes and premium price strategy : A study of Tea consumers in middle and high end markets, Journal of Management Matters , University of Rajarata, 3(1), $13-20$

Rathnayake R.M.S.L. and P.I.N. Fernando (2017). Do emotional states of the consumers play a mediating role amongst visual merchandising strategies and purchase intention?, Journal of Management Matters , University of Rajarata, 4 (1) , 59-74

Santouridis, I. (2009). e-Service quality and its impact on customer satisfaction and trust : an empirical study on greek customers of internet shops. 6th International Conference on Enterprise Systems, Accounting and Logistics (6th ICESAL '09), May, 17-31.

Sin, L. Y, Tse, A. C., Yau, O. H., Lee, J. S. \& Chow, R. (2002). The effect of relationship marketing orientation on business performance in a service-oriented economy. Journal of Services Marketing, 16(7), 656-676. https://doi.org/10.1108/08876040210447360

Singh, J., \& Sirdeshmukh, D. (2000). Agency and trust mechanisms in consumer satisfaction and loyalty 
judgments. Journal of the Academy of Marketing Science, 28(1), 150-167. https://doi.org/10.1177/0092070300281014

Sundaram, V., Ramkumar, D., \& Shankar, P. (2017). Impact of e-service quality on customer satisfaction and loyalty empirical study in India online business. Kinerja, 21(1), 48. https://doi.org/10.24002/kinerja.v21i1.1034

Tsiros, M., \& Heilman, C. M. (2005). The effect of expiration dates and perceived risk on purchasing behavior in grocery store perishable categories. Journal of Marketing, 69(2), 114-129. https://doi.org/10.1509/jmkg.69.2.114.60762

Wang, Yuan, Lu, J., Xu, F., \& Zhang, L. (2006). Trust measurement and evolution model for internetware. Ruan Jian Xue Bao/Journal of Software, 17(4), 682-690. https://doi.org/10.1360/jos170682

Yang, Z., \& Fang, X. (2004). Online service quality dimensions and their relationships with satisfaction: A content analysis of customer reviews of securities brokerage services. International Journal of Service Industry Management, 15(3), 302-326. https://doi.org/10.1108/09564230410540953

Zeithaml, V. A., Parasuraman, A., \& Malhotra, A. (2002). Service quality delivery through web sites: A critical review of extant knowledge. Journal of the Academy of Marketing Science, 30(4), 362-375. https://doi.org/10.1177/009207002236911 